\title{
Climate governance and International Civil Aviation: Brazil's policy profile
}

DOI: http://dx.doi.org/10.1590/0034-7329201900203

Rev. Bras. Polít. Int., 62(2): e003, 2019

Revista Brasileira de Política Internacional ISSN 1983-3121

http://www.scielo.br/rbpi

\section{Veronica Korber Gonçalves ${ }^{1}$}

${ }^{1}$ Universidade Federal do Rio Grande do Sul, Departamento de Economia e Relações Internacionais, Porto Alegre, Brasil. (vkgoncalves@gmail.com)

iD ORCID ID: orcid.org/0000-0001-7144-4707

\section{Marcela Anselmi}

${ }^{2}$ Agência Nacional de Aviação Civil Assessoria Internacional, Brasília, Brasil. (marcela.anselmi@anac.gov.br)

\section{Copyright:}

- This is an open-access article distributed under the terms of a Creative Commons Attribution License, which permits unrestricted use, distribution, and reproduction in any medium, provided that the original author and source are credited.

- Este é um artigo publicado em acesso aberto e distribuído sob os termos da Licença de Atribuição Creative Commons, que permite uso irrestrito, distribuição e reprodução em qualquer meio, desde que o autor e a fonte originais sejam creditados. 
to the set of actions taken by state and non-state actors to deal with the issue of climate change. Recognizing aviation emissions as contributors to changes in the global environment system also requires the enlargement of the scope of analysis, in order to consider the ethical implications of the consequences of climate change to local communities and to the environment.

We describe the route to the agreement reached by ICAO's $39^{\text {th }}$ Assembly, in order to contextualize CORSIA's final design and highlight some of its limitations. Two main factors contributed to the agreement: the role of the European Union, which sought to lead the negotiations, and the choice of a flexible and ultimately weak market-based mechanism that received support from the international airlines. We address the ICAO negotiations considering the relevant actors, especially states, airline companies and non-governmental international organizations, without a pre-assumption of hierarchy among them. Hereafter, we analyze the Brazilian position at ICAO in order to define the Brazilian policy profile, considering its foreign policy and positions at the negotiations. In the last part, we present the debate about CORSIA in Brazil, highlighting different local actors' views about the mechanism.

\section{Theoretical and methodological framework}

We take two dimensions into account to define Brazil's policy profile (Viola and Franchini 2017) in relation to international civil aviation emissions regulation negotiations: a) the country's climate foreign policy at ICAO and, b) the domestic policies related to aviation emissions in Brazil, as a way to surpass the political discourse and take into account effective measures taken by actors in order to define the domestic politics - if any - in this issue area. Therefore, it is necessary to consider Brazil both as an actor in an international forum and, at the same time, as a national arena in which different actors (domestic, international and transnational actors) seek to construct and to influence decision making concerning climate policies.

Regarding the initially stated purpose, we intend to classify the Brazilian negotiation role at ICAO as a reformist or a conservative actor (Viola et al. 2013). Since negotiations concerning aviation emissions were blocked for almost two decades, we could consider Brazil a reformist actor if the state has pushed towards a global agreement (CORSIA), or a conservative actor if its active positions have prioritized to prevent changes in the status quo and to seek the so-called national interests - or, in the specific context of aviation negotiations, - the sectorial interests.

In addition, we can classify Brazil's posture at the negotiations as reactive or proactive (Dee 2015). Brazil would be reactive if the elements indicated that the country did not engage in negotiations and has avoided responsibilities and obligations, or a proactive actor if it has participated at the ICAO's meetings in order to exercise authority in the agenda setting and propositions to defend an agreement or even acted to maintain the status quo of any resolutions referring to aviation emissions. Adapting DEE's scheme $(2015,37)$, this classification can be summarized as follows: 


\begin{tabular}{|ll|}
\hline \multicolumn{1}{|c|}{ Reformist } & \multicolumn{1}{c|}{ Conservative } \\
\hline - Proactive & - Proactive \\
- Reactive & $\bullet$ Reactive \\
\hline
\end{tabular}

Figure 1. Classification of the actor's posture at negotiations

Considering the image, we intend to classify the Brazilian role in the negotiations involving CORSIA at ICAO based on the ICAO reports and meetings memoires from 2008 to 2017, besides the Brazilian official documents published in the same period.

In order to encompass the second dimension, we find the theoretical framework of our analysis in the literature of global governance, as it provides a lens to identify power relations among different actors in different arenas, crossing the boundaries set by formal rules and institutions. Then, it is possible to analyze ongoing disputes over decisions. Global governance is the result of political processes in an arena with multiple actors (from international organizations to local community organizations) interested in "governing" activities in issue areas of their concern (Avant et al. 2010).

The study of this political process allows us to recognize which political variables have helped to define a specific problem as a global problem, and who will be legitimized to deal with it. Then, it is possible to answer where, how and why different actors deal with the issue in a specific political context. It also describes the power arrangements that change the balance of power and reinvent governance, defining the agenda. Without presuming that states are the main actors, we seek to discover who are the global governors, defined as "authorities who exercise power across borders for purposes of affecting policy. Governors thus create issues, set agendas, establish and implement rules or programs, and evaluate and/or adjudicate outcomes" (Avant et al. 2010, 2).

Considering that CORSIA may have political, environmental and social impacts in different localities, different actors (subnational Brazilian states, transnational social movements, and companies, among others) have engaged in presenting specific agendas in Brazil, supporting CORSIA as an opportunity or resisting to it. These social dynamics reflect a political process that addresses a "global" problem (international civil aviation emissions) with specific local political responses and solutions, and may influence the international arena, blurring differences between the level of domestic and international politics. In this sense, Brazil is not considered as a "black-box," but as a plural actor, "and its behavior resembles not a rational player with an undeviating national interest, but a resultant of a complex social process that involves forces from civil society, the market, and the government" (Viola and Franchini 2017, 30). Therefore, Brazil is an arena in which actors seek to interpret and reinterpret global problems and global solutions, and this specific arena is part of the fragmented architecture of global climate governance (Biermann 2010). 
Finally, the recognition of aviation emissions as contributors to changing the global environmental system requires the enlargement of the scope of analysis, in order to consider some of the ethical implications of the consequences of climate change and of the political solutions to local communities and to the environment. We then analyze CORSIA considering its ethical implications, pointing towards some of its limits not in a state-centric approach (i.e., considering its implications to the countries involved), but also to the environment, which requires us to evaluate if it promotes global reduction of GHG emissions and at what cost to the local environment. In the last section, we present some of the impacts according to one of the local communities potentially affected by CORSIA.

\section{Negotiations and the ICAO's 39th Assembly Agreement}

ICAO was established in 1944 by the Chicago Convention, and its primary goal is to promote the standardization of norms and procedures related to safety, security, facilitation, and economic development of civil aviation (International Civil Aviation Organization 1944). As a sectorial international organization, ICAO establishes the so-called Standards and Recommended Practices (SARPs), which are adopted by Member-States and internalized in their national regulations.

Environmental concerns have historically been treated by ICAO from the strict point of view of the civil aviation impact on local air quality and noise disturbances in the vicinity of airports. Nevertheless, as the environmental agenda intensified, the Organization needed to adapt its structure to respond to new challenges. In this regard, the Committee on Aviation Environmental Protection (CAEP) was created in 1983, as a technical committee directly linked to the Council. It is mainly aimed at studying and developing proposals to minimize aviation's effects on the environment.

Air transport though, is an important polluter of GHG, as it is responsible for two percent of the anthropogenic $\mathrm{CO}_{2}$ emissions (Intergovernmental Panel on Climate Change 2007, 47). Approximately two-thirds of this volume stems from international aviation (International Civil Aviation Organization 2016a, 97). Despite this fact, discussions on how to reduce the impact of civil aviation on climate change were only inserted on ICAO's agenda in the 1990's as a response to the international climate regime. However, the UNFCCC was broad enough not to mention any commitment for specific sectors, nor for international transportation.

The Kyoto Protocol, in turn, has given a very clear negotiating mandate to ICAO (Article 2(2)). As the sectorial organization, ICAO should come to an agreement to limit or reduce GHG from civil aviation that were not controlled by the Montreal Protocol of 1987. Nevertheless, consensus was difficult achieve under ICAO, mainly because of the possible negative impact that it could entail for the industry. Particularly, there was great concern over market distortions that could be raised if only developed countries had obligations to compensate or reduce their airline emissions. The International Air Transport Association (IATA), which represents the larger air 
carriers in the world and acts as an observer member at ICAO, expressed its support to mechanisms to further limit or reduce aircraft $\mathrm{CO}_{2}$ emissions, under one condition though: any measure should be based on three overriding objectives, namely, the protection of air transport's ability to grow, the reduction of costs of any regulatory measure, and the minimization of any competitive distortion between aviation participants and between aviation and other modes of transport (International Civil Aviation Organization 2004).

Developing states, in turn, have emphasized the fact that one of the principles enshrined in the UNFCCC is that industrialized countries were required to take the lead in addressing GHG emissions. In this regard, the principle of Common But Differentiated Responsibilities (CBDR) was inserted within ICAO's agenda as developing states demanded special treatment according to the level of development of their industry. Consequently, developing states, including Brazil, fiercely rejected any agreement that was not based on the CBDR principle. Developed countries and the industry (i.e., IATA), on the other hand, had strongly advocated for the non-discrimination principle as it was enshrined in the Chicago Convention.

The analysis of the countries' interests and position at the ICAO is not as straightforward as in the global climate regime though. This common division between developed and developing countries does not always apply in the case of the ICAO. With a strong presence of the private sector, ICAO is highly influenced by market concerns. In this sense, it may be more effective to analyze the main actors' position according to the level of development of their aeronautical industry. Airlines in emerging countries, especially in China, have an above-average growth projection and they have been major competitors of traditional markets, such as Europe and the United States. According to IATA's projections, by 2034 China will likely have surpassed United States as the largest global air passenger market, followed closely by India in the third position. Highly developed domestic markets including Italy, France, Spain, and the UK are all expected to drop down the ranks (International Air Transport Association 2015).

It may be argued, thus, that a division based on market interest was created at the ICAO and a deadlock hindered any substantive agreement to curb $\mathrm{CO}_{2}$ emissions from civil aviation. Under this scenario, the European countries played an important and decisive role as normative leaders (Gonçalves 2016). Responding to the European Commission Directive that included regional civil aviation in the European Emission Trading Scheme (EU ETS), ${ }^{1}$ non-European states and the industry rejected any unilateral actions from states or grouping of states (International Civil Aviation Organization 2007).

Given this scenario of possible proliferation of different trading schemes, the first step taken by ICAO was the adoption of Resolution A37-19 in 2010. In addition to affirming the global aspirational goals for the international aviation sector of improving annual fuel efficiency by $2 \%$, the Resolution also established the commitment of states to the global goal of the carbon neutral

\footnotetext{
1 In 2008 the European Commission issued Directive 2008/101/EC, through which all flights with origin or destination in a European country would have to compensate their emissions by the European ETS beginning in 2012. Non-European members, such as Iceland, Liechtenstein and Norway, also adhered to the initiative.
} 
growth sector from 2020 onwards. To this end, a basket of measures should be established including technological and operational improvements, the use of alternative fuels and the adoption of market-based measures on a provisional basis.

The prospect of including all international flights overpassing the European territory in the EU ETS, from 2016 onwards, prompted the ICAO to act more incisively. As a way to avoid the creation of a patchwork of different offsetting schemes, the European states agreed on a stop-the-clock-policy. The European countries would give one year for the ICAO to move forward in designing a global MBM scheme aimed at reducing emissions from international aviation (European Commission 2012). This policy has ultimately allowed for the necessary room for the political negotiations. The industry's willingness to create a single, global scheme in its scope with the lowest cost to airline companies also helped discussions (International Civil Aviation Organization 2007). As a result, the ICAO decided to develop a global MBM scheme for international aviation to be implemented from 2020 onwards. The principle of the CBDR should be the basis for any MBM scheme, while minimizing market distortions. This was a compromise to accommodate developing and developed countries' interests alike.

The path to CORSIA was settled. Negotiations under ICAO were highly intense as the organization was under pressure to reach compromise among its members. The countries' position on the matter were clearly posed. On one hand, developing countries, especially Brazil, China and Russia, were deeply concerned with the development of discussions under ICAO (International Civil Aviation Organization 2016c). They were also fiercely advocating that any agreement should be based on the CBDR principle and should also be aligned with the UNFCCC regime. On the other hand, the United States, European states and the industry (i.e., IATA) were strongly emphasizing the need for a simple and non-discriminatory scheme (International Civil Aviation Organization 2016d).

Against this background, Resolution A39-03 was adopted, and a global market-based measure scheme was established in the form of the Carbon Offsetting and Reduction Scheme for International Aviation (CORSIA). The main objective of this scheme, - which was meant to be temporary, - is to address any annual increase in total $\mathrm{CO}_{2}$ emissions from international civil aviation above the 2020 levels, taking into account special circumstances and respective capabilities (i.e., CBDR) and the non-discrimination principle (International Civil Aviation Organization 2016b). In other words, as the aviation sector has not developed enough internal measures to mitigate its own emissions, it will have to foster reduction of $\mathrm{CO}_{2}$ emissions from other sectors, in order to be able to continue its emissions level.

In general terms, CORSIA will be implemented in two main phases: the first phase will be from 2021 to 2026 and will include only countries that volunteer to participate in the offsetting scheme. From 2027 onwards, CORSIA will be obligatory for all states that have a significant individual share of international aviation activities in RTKs in year 2018 above 0.5 per cent of total RTKs, or that are part of the $90 \%$ world RTK. Exception will be granted to Least Developed Countries (LDCs), Small Island Developing States (SIDS) and Landlocked Developing Countries 
(LLDCs) unless they volunteer to participate in any phase. Through this voluntary approach, the ICAO sought to contemplate the CBDR principle without formally establishing a list of developed vs. developing countries. The tacit agreement seems to have been the participation of China, as a large competitor in the first phases of the scheme, as the condition for the United States' acceptance of any climate agreement under the ICAO ("Fact sheet: U.S.-China Cooperation on Climate Change." 2016). The non-discrimination principle was contemplated in the so-called route approach. According to this approach, the carbon offset scheme will only apply if the countries of origin and destination are both participating in CORSIA; otherwise, the route is exempt from offsetting obligations. Therefore, nationality is not considered when attributing offsetting requirements to an operator, but rather the route that is operated.

Once the set of routes that are part of the scheme is defined, between 2021 and 2029, the distribution of offsetting obligations will be made according to the market share of each air carrier. In this sense, more consolidated airlines with a larger share of the global RTK and, thus, with greater GHG emissions, will pay relatively more than smaller operators. Starting in 2030, though, individual factors will increasingly be added in the calculation of the offsetting requirements of each air operator. When this individual factor is included, the need for offsetting emissions will be established not only by the market share of the airlines, but also by their individual growth rate. As a result, new entrants or non-mature airlines, whose growth rates are usually very high but with a relatively small market share, will pay proportionately more than mature companies.

This mechanism to distribute offsetting obligations may have subverted both the CBDR and the non-discrimination principles, potentially creating significant market distortions between airline operators. On one hand, when the individual factor enters into force, airlines operating the same route will have different offsetting obligations and, thus, different costs, creating a highly distortive regulatory framework. On the other hand, airlines from developing countries have a smaller market share in the global RTK, but are faster-growing companies. In this case, it is highly possible that air operators from the developing and emerging economies will pay a larger share of the CORSIA scheme.

\section{Limits of CORSIA}

CORSIA is the result of a negotiation process in an International Organization (IO). IOs tend to produce "lowest common multiple" decisions, and CORSIA is a good example of this lack of stringency. It is a system designed to allow flexible compliance of rules. The central interests mediated in the negotiations that resulted in the approval of CORSIA were trying to preserve the sectorial growth and the national interests involved while also responding to climate change.

The main governor (Avant et al. 2010) in defining CORSIA's scope were airline companies (Gonçalves 2016), which are extremely efficient in lobbying and orienting states' positions at 
ICAO so that the results of negotiations are not too harmful to their business. After articulating a very hard opposition to the EU ETS, and since airline companies realized that some kind of regulation involving carbon emissions were hard to avoid, they clearly indicated a preference for an offsetting mechanism and played an important role on designing the scheme (International Air Transport Association 2016). Therefore, airline companies and states were the main actors pushing the agenda towards a market-based mechanism².

Other actors have been less enthusiastic about the results of negotiations and have been underlining some of the limits of the agreement achieved. Non-Governmental Organizations and civil society networks that observe the meetings and lobby for different (and stringent) results have classified the CORSIA Resolution as a weak agreement, although it represents an important first step. The main problem is that the Resolution does not set clear parameters to guarantee the environmental integrity of the credits allowed at CORSIA. Some important elements are still at the negotiation table, in particular those related to the quality of carbon offsetting credits and the criteria for their eligibility under CORSIA.

The International Coalition for Sustainable Aviation (ICSA), the official environmental civil society observer at the ICAO, stressed that CORSIA still is not transparent and detailed enough, and the negotiations about the CORSIA Package must define clearly which "eligible emissions units" will be allowed for compliance with CORSIA ("Global Aviation CO2 Deal Adopted With Mixed Results, Just As Paris Agreement Takes Off.” 2016). Transport \& Environment (T\&E), an NGO that lobbies specially at the EU, has stated that CORSIA has too weak reduction targets, and that offsetting makes it even easier to achieve, since offset credits are the cheapest at the carbon market. In that sense, CORSIA would not be ambitious enough.

Besides, the voluntary design in its initial phases and the absence of a strong commitment about the quality of the offsets indicate that the system may not be able to incentivize the aviation sector's transition to more efficient technologies (Murphy 2018). World Wild Fund (WWF) UK expressed a similar position. It considered that offsetting is a limited mechanism that should not substitute other policies that actually induce emissions reduction. Besides, WWF stresses that there are records of socio-environmental impacts caused by offsets projects (World Wildlife Fundation UK 2016). ICAO negotiations resulted in weak emission targets which do not express the total amount of aviation emissions, and offsetting is a shortcut for the sector in order to respond to the climate problem without the need for large or expensive changes (Beard 2017). In the same sense, the Aviation Environment Federation (AEF) see CORSIA as a weak result and market-based mechanisms merely as intermediate term solutions (Aviation Environment Federation 2017).

Another important aspect of the Resolution A39-03 is that it also has presented the possibility for air operators to claim offsetting reductions from the use of sustainable alternative fuels, as a way to encourage the use of cleaner alternatives to aviation bunker fuel. This creates a possibility

\footnotetext{
2 We recognize differences among punctual states' positions, like EU states, that advocated for a cap and trade system, and Venezuela, Russia, India, Saudi Arabia, which presented reservations to CORSIA Resolution.
} 
for enhancing this nascent industry in the developing countries, especially in Brazil, which has a very competitive and promising production. Nevertheless, ICAO members seem to be very irresolute on what the future of sustainable alternative fuel for international aviation will be. While establishing these as part of the incentives for reducing $\mathrm{CO}_{2}$ emissions under CORSIA, it has also been very reticent in expressing strong support to alternative fuels (International Civil Aviation Organization 2017).

Alternative fuels, and particularly biofuels, are a very controversial issue as they may cause as much harm to the environment as conventional fuels. Presented as part of the solution for a more balanced energy matrix (International Air Transport Association 2017), they could only be considered as part of a climate policy strategy if produced in a sustainable manner, taking into account economic, social, and environmental criteria, in order to avoid, for example, land grabbing (Clements and Fernandes 2013). That is one of the main issues of conflict among the Brazilian actors involved with the theme, as we see next.

Nevertheless, given the projections of an increasing demand, the industry will hardly find internal solutions to curb its emissions. Following the argument, if sustainable alternative fuels are not developed in a larger scale to meet the current and future demand, CORSIA may become a permanent scheme, lasting much beyond 2035, when it was supposed to come to an end. As a result, a considerably weak mechanism will probably be maintained as the main international policy instrument to deal with aviation emissions.

\section{The role of Brazil at CORSIA's negotiations}

In order to evaluate the role of Brazil in CORSIA's negotiations, it is important to highlight, at first, that Brazil is an important player in the air transport sector. With an extensive territory and a very poor transportation system, domestic air transportation constitutes an important means of connecting people between regions in Brazil. According to official data, in 2016, 109,6 million passengers were carried in domestic and international flights, with a growth rate of $87 \%$ from 2007 to 2015 (Agência Nacional de Aviação Civil 2016, 79). If both domestic and international flights are considered together, Brazil is the fifth largest market in the world (Agência Nacional de Aviação Civil 2015), with projections to jump to the fourth place in the next 25 years (International Air Transport Association 2016). Considering only the international flights, though, Brazil ranks in the 28th position of the global RTK (International Civil Aviation Organization 2016h).

Air transport is responsible for approximately $0.5 \%$ of the GHG emissions in Brazil. Nevertheless, this proportion will probably rise as emissions from aviation have increased at a faster pace when compared to the other sectors of the Brazilian economy. If one considers only international flights operated from/to Brazil, the GHG emissions have grown at a 4.5\% annual rate from 2005 to 2015. Despite these figures, though, energy efficiency from international 
operations in Brazil was $2.3 \%$ in the period, very close to the goal established by the ICAO of a 2\% increase in efficiency annually (Agência Nacional de Aviação Civil 2015).

The Brazilian government's position in the ICAO negotiation process was very aligned to the industry's interests, and the government's agenda in the domestic debates is very close to that of the air transport sector (Brasil 2016). With the backdrop of the international climate regime principles, Brazil strongly advocated for the CBDR principle as the basis for any climate agreement under the ICAO (International Civil Aviation Organization 2016c; 2016e; 2016f; 2016g). The main concern expressed by Brazil during the whole process was related to the possibility that a global MBM could impose a disproportional economic burden on developing countries, where the international aviation market is still maturing.

In addition, Brazil also emphasized the need for considering the CBDR principle not only at the phase-in approach, but also at the distribution calculation of offsetting requirements. During the $39^{\text {th }}$ ICAO Assembly, the Brazilian Government expressed concerns on the inclusion of an individual factor for the distribution of offsetting obligations, as it could generate more market distortions, with a large difference in relative offsets costs across routes. Brazil was thus a strong supporter of the so-called $100 \%$ sectorial formula, as it would penalize its own air carriers less, which have more potential of increasing their emissions in the medium-term.

Another aspect of the Brazilian position was the clear demand for a special treatment for the offset credits generated under the UNFCCC mechanisms (i.e., the Sustainable Development Mechanism). Those unit emissions should be automatically eligible and should be given preference in the implementation of CORSIA, a demand not included in the final text of the Resolution A39-3. One of the reasons for this stance on the eligible emissions units rests on the fact that Brazil was one of the main players in the former Clean Development Mechanism (CDM), as an important amount of the offsetting credits generated were from Brazilian projects. In this sense, Brazil could also benefit from CORSIA by consolidating itself as an important offsetting credits supplier.

International and Brazilian NGOs have criticized the Brazilian position, though, arguing that Brazil was trying to revive "a relic of the Kyoto Protocol" (Schwartzman 2017). The Environment Defense Fund (EDF) and the Instituto Socioambiental (ISA) stated their concern on the environmental and financial integrity of the Brazilian hydroelectric projects (Environment Defense Fund 2017), which represents an important amount of the country CDM credits.

Considering the route to the ICAO's agreement and the scope of CORSIA's final design, Brazil was not a reformist actor in the negotiation process, since it did not work to strength the environmental integrity of the ICAO response to the need of the sector's emission reduction. Besides, on several occasions, Brazil insisted on the consideration of the principle of Common But Differentiated Responsibilities and did not offer a political solution that this principle entailed for the negotiations. In this sense, Brazil cannot be considered a proactive actor in the negotiation process, despite the contribution with the proposal of the route approach. In this context, we classify Brazil as a reactive conservative state, since the country has prioritized the 
interests of its own airlines and the possible effects that CORSIA would have on the sector, and did not lead or push the negotiations towards achieving a stronger and environmentally significant agreement to promote international aviation GHG emissions reduction.

\section{Different views about CORSIA in Brazil}

Two of the most important institutional actors in Brazil are the National Civil Aviation Agency and the National Civil Aviation Secretary of the Ministry of Transport, Ports and Civil Aviation. Both of the federal governmental institutions subsidize the Brazilian work at the ICAO, especially the Ministry of Foreign Affairs, which has led the negotiation process. Within the aviation sector, the Brazilian Airlines Association (ABEAR) comprises the main national airline companies.

Besides CDM, both the federal government and air transport sector see biofuels as a great opportunity for the country. ABEAR expects that the national environmental policy be concentrated in technological advances, operational improvements, and alternative sustainable fuels. With these mitigation measures there would be no need to implement any compensation mechanism nationally (Associação Brasileira das Empresas Aéreas 2017). Nonetheless, since the creation of the Brazilian National Alcohol Program and the large-scale production of ethanol, scientists and academics of various fields of study have been pointing to the environmental impacts caused by the supply chains of raw materials for obtaining biofuels. Hence, it would be important for aviation sustainable fuels policies to use this past experience and avoid its social and environmental impacts.

Another important actor is the Brazilian Forum on Climate Change (Fórum Brasileiro de Mudanças Climáticas - FBMC), a forum constituted by civil society actors and government representatives (national and subnational), and whose main goal is to raise awareness, mobilize society, and contribute to the discussion in the fight against climate change. In 2018, the FBMC published an Implementation Proposal for the Brazilian Intended Nationally Determined Contributions (INDCs) presented under the Paris Agreement commitments (Fórum Brasileiro de Mudanças Climáticas 2018). The proposal summarizes the debate held in nine Thematic Groups since March 2017.

CORSIA is mentioned in the document in the "transport and mobility" chapter. The document states that a national politics for biokerosene production would help Brazilian companies to comply with CORSIA obligations and would also allow the development of a low carbon national aviation sector, contributing to the achievement of the Brazilian INDC. According to the document: "There is great future potential in the global biokerosene market (estimated at 314 million $\mathrm{m}^{3} /$ year). In the short term, Brazil has good conditions for producing and establishing bilateral partnerships for the supply of aviation biokerosene" (Fórum Brasileiro de Mudanças Climáticas 2018, 19-20). 
The debate about CORSIA in Brazil also includes the offset credits from forest projects and REDD+. FBMC has created a Working Group on Forest Offsets on CORSIA/ICAO. In a meeting held in the city of Rio Branco, in the state of Acre in May 2017, the Group preliminarily concluded that there may not be technical impediments to the inclusion of forest and REDD+ offsets in the CORSIA mechanism. According to the Group, emissions reduction from avoided deforestation and carbon sequestration by forestry activities could fulfill the requirements defined by CORSIA. The risks of leakage and non-permanence could be avoided with technical and scientific knowledge (Fórum Brasileiro de Mudanças Climáticas 2017). The conclusions of this Working Group were not included in the final document cited above, and hence do not represent the position of the FBMC.

A few days after, in a city near Rio Branco called Xapuri, another group has also discussed forest offsets. The meeting, named "The effects of environmental/climate policies on traditional populations," brought together Apurinã, Huni Kui, Jaminawa, Manchineri, and Shawadawa indigenous people, as well as representatives of traditional communities of Acre and rubber tappers. The meeting was supported by the Indigenous Missionary Council (CIMI), the Rosa Luxemburg Foundation, the World Rainforest Movement, and Friends of the Earth International. The group denounced that indigenous people and traditional populations were not invited to the Rio Branco meeting, despite the fact they are the most impacted by the projects. As explained by Dercy Teles de Carvalho Cunha, President of the Xapuri Rural Workers Union:

They use the issue of global warming as psychological terror in people's heads, as if rubber tappers preserving the forest alone was enough to resolve the world's climate problem. Last year, I told a prosecutor on environmental issues that I understand that the climate is changing, but it's not by forcing us, traditional people, to stop growing our subsistence crops, for which we only burn once a year, that you're going to solve the problem. The impact of the Bolsa Verde (Green Grant) program is the loss of all the rights the peoples have as citizens. They lose all control over their territory [...] This takes away a human being's true meaning of life (Faustino and Furtado 2013, 5).

At the end of the meeting, the group published the "Xapuri Declaration" claiming forests offset represents some form of climate colonialism, and expressing concern about aviation emissions compensation through REDD mechanisms. The group also expressed:

Indignation about the false solutions, which legitimize the continuity and expansion of a socially and environmentally destructive model. We reject initiatives to offset pollution. We do not accept mechanisms based on restrictions on our way of life, and we express solidarity with people living in the areas that are contaminated by companies seeking compensation (offsets). We stand by the people from other countries who live in the areas impacted by the pollution generated by destructive companies. No one should live in contaminated areas; it is time to end all kinds of racism, including environmental racism ("Xapuri Declaration: 'We Reject Any Form of Climate Colonialism'." 2017). 
This excerpt illustrates some of the hidden impacts of a climate policy centered only on the global scale (Gonçalves 2017). The politic of scales (Gupta 2008) can be used by actors in order to present one solution to the detriment of others. When the focus is carbon metric, it is possible to deal with the problem of global aviation emissions with compensation projects at the local level, camouflaging local impacts as 'losing control over the territory' (Gilbert 2016). The Brazilian debate about forest offsetting indicates that there was no consistent dialogue concerning CORSIA, especially because some of the potentially affected people could not express their opinion about the proposals that may change their way of living.

In July 2017, 51 organizations and social movements from different parts of Brazil filed a letter to the Ministry of Foreign Affairs and the Ministry of Environment. The "Letter in defense of Brazilian historical position on forest offsets" states that forests offsets are a false solution that would benefit a small number of national and international actors, but with very serious consequences to local communities, to the country and to the global environmental system as a whole. Besides, they claim that forest offsets are being discussed at the same time that the federal government and the National Congress is producing a historic and tragic setback of protective environmental laws and policies (Amigos da Terra Brasil et al. 2017).

Apart from that, the government's position at the ICAO was not legitimized by an open public debate. There was not any kind of public hearing or consultation about the country's position at the ICAO. CORSIA may end up transferring the cost of compensating aviation emissions to the passengers, since airline companies may include the costs of buying offset credits in the final consumers' tickets. This will probably affect Brazilian consumers, but there has not been a public discussion about it yet. In addition, the Brazilian position was not justified or linked with the Brazilian National Climate Policy (Federal Law n. 12.187, approved in 2009), which indicates that they are not integrated policies in order to achieve a common objective (a climate change national strategy).

In summary, CORSIA may have specific impacts in Brazil, specially related to land use, and local and national actors are struggling to defend their points of view - with different capacities of organization, financing and influencing decisions. The lack of public debate about these impacts and the absence of coordination with the national climate policy have been central to the prevalence of market interests.

\section{Conclusion}

CORSIA is a limited policy because it maintains a polluting social practice and does not prioritize the social and ecological impacts, but rather the smoothing of the mechanism's economic effects. Among its limits, the offsetting scheme creates a geographical and symbolic distance between pollution and the polluters. When it transforms the intensive emitters of greenhouse gases into participants in a system, there is no individual responsiveness, but rather a general 
incentive to prioritize actions with better economic cost-benefit. Therefore, offsetting blurs the cause-consequence link and dilutes the social and environmental responsibility for emissions.

CORSIA is a weak response to the problem of climate change and it displaces potentially stronger policies to induce the promotion of higher efficiency gains. Besides, considering CORSIA's final design and the negotiations related to criteria involving the quality of the carbon credits (still under discussion at ICAO), CORSIA may imply an effective greenwash for airline companies.

The role of Brazil in CORSIA's negotiations did not incite a stronger agreement in an environmental perspective, which means that the country did not lead or push to an agreement with more responsibilities and obligations to the parties involved. In this sense, we classify Brazil as a reactive conservative state. Brazil, as other countries at the ICAO's negotiation table, has defended its airline interests in detriment of a more effective international aviation GHG emissions reduction system. Considering specifically the Brazilian reality, CORSIA may encourage the expansion of offset projects, changing local political dynamics and resulting in different environmental impacts without a public dialogue, especially with affected local communities.

\section{References}

Amigos da Terra Brasil et al. Carta em defesa da posição histórica do Brasil sobre offsets florestais. July 11, 2017. https://bit.ly/2HQV1 iw

Associação Brasileira das Empresas Aéreas - Abear. "Aviação e mudanças do clima: CORSIA e tendências: Biocombustível, solução definitiva?” Paper presented at the Seminário: Biocombustíveis e a Aviação - Impactos Técnicos e Econômicos, São Paulo, September 21, 2017. http://www.abear.com.br/uploads/arquivos/eventos_ptbr/2_-_ana_machado.pdf Agência Nacional de Aviação Civil - ANAC. Anuário do Transporte Aéreo. Brasília, DF: ANAC, 2016. https://bit.ly/2Phc7dD

Agência Nacional de Aviação Civil - ANAC. Plano de Ação para a redução das emissóes de gases de efeito estufa da aviação civil brasileira: ano base 2015. Brasília, DF: Imprensa Nacional, 2015. Accessed https://bit.ly/2HP2Y7R

Avant, D. D., M. Finnemore, and S. S. Sell, editors. Who Governs the Globe? New York, NY: Cambridge University, 2010.

Aviation Environment Federation - AEF. Is aviation climate policy heading in the right direction? Aviation Environment Federation blog, October 2, 2017. https://bit.ly/2EMWggC

Beard, J. Grounded: Ten reasons why international offsetting won't solve Heathrow's climate change problem. London: WWF UK, 2017. Accessed https://bit.ly/2wyxoVn

Biermann, F. "Politics for a New Earth: Governing in the 'Anthropocene'." In New Earth Politics, edited by S. Nicholson, and S. Junnah, 405-420. Cambridge, MA: The MIT Press, 2016. https://doi.org/10.7551/mitpress/9780262034364.003.0017 
Brasil. Relatório de Atividades - 2016. Brasília, DF: Senado Federal, 2016. https://bit.ly/2MmJr2U Clements, E. A., and B. M. Fernandes. "Land Grabbing, Agribusiness and the Peasantry in Brazil and Mozambique." Agrarian South: Journal of Political Economy 2, no. 1 (2013): 41-69. https://doi.org/10.1177/2277976013477185

Dee, M. The European Union in a Multipolar World: World Trade, Global Governance and the Case of the WTO. Hampshire: Palgrave Pivot, 2015.

Environment Defense Fund - EDF. “Brazil's Amazon Hydroelectrics in the United Nations Clean Development Mechanism (CDM): Defrauding Investors, Cheating the Atmosphere?” November 2017. Accessed https://bit.ly/2QEi4jc

European Commission - EC. "Stopping the clock of ETS and aviation emissions following last week's International Civil Aviation Organisation (ICAO) Council.” Europe Commission Press Release Data Base, November 12, 2012. http://europa.eu/rapid/pressrelease_MEMO-12-854_en.htm

"Fact sheet: U.S.-China Cooperation on Climate Change." US Embassy in Brazil, September 3, 2016. https://bit.ly/2KebnmO

Faustino, C. and F. Furtado. The green economy, forest peoples and territories: rights violations in the state of Acre. Rio Branco, AC: DHesca, 2013. Rapporteur on the human right to the environment. https://bit.ly/2wtvmG2

Fórum Brasileiro de Mudanças Climáticas - FBMC. "Grupo de Trabalho de Offsets Florestais no CORSIA/ICAO." Paper presented at 2nd Reuniáo Técnica. Rio Branco, AC, 2017. https://bit.ly/2QIJOTW

Fórum Brasileiro de Mudanças Climáticas - FBMC. Proposta de implementação da INDC brasileira. Brasília, DF: FBMC, 2018. https://bit.ly/2WD9oPp

Gilbert, J. "Land grabbing, investors, and indigenous peoples: new legal strategies for an old practice?” Community Development Journal 51, no. 3 (2016): 350-366. doi: https://doi.org/10.1093/cdj/bsv025

Gonçalves, V. K. A união europeia na governança do clima: o caso da aviação civil internacional. Brasília, DF: UnB, 2016. http://repositorio.unb.br/handle/10482/21330.

Gonçalves, V. K. "Climate Change and International Civil Aviation

Negotiations." Contexto Internacional 39, no. 2 (2017): 443-458. doi: https://doi.org/10.1590/s0102-8529.2017390200012.

Gupta, J. "Global change: analyzing scale and scaling in environmental governance." In Institutions and Environmental Change: Principal Findings, Applications, and Research Frontiers, edited by O. R. Young, L. A. King, and H. Schroeder. Cambridge, MA: MIT Press, 2008.

International Air Transport Association - IATA. Air passenger forecasts: Global report. Montreal: IATA, 2015. https://bit.ly/2W7nnc1

International Air Transport Association - IATA. "Resolution on the development of a global market-based measure for international aviation." Paper presented at the 72 nd IATA Annual General Meeting, Dublin, 2016. https://bit.ly/2WE9XZk 
International Air Transport Association - IATA. 2017. Sustainable Alternative Jet Fuels (SAF). Montreal: IATA, 2017. https://bit.ly/2ge3pgT

Intergovernmental Panel on Climate Change - IPCC. "Climate change 2007: mitigation of climate change." Paper presented at the Group III to the Fourth Assessment Report of the IPCC, New York, NY, 2007. https://bit.ly/2wyiazK

International Civil Aviation Organization - ICAO. Chicago Convention. Chicago, IL: ICAO, 1944. https://www.icao.int/publications/Documents/7300_orig.pdf

International Civil Aviation Organization - ICAO. Aviation and climate change. Assembly Working paper n. A35-WP/85. Montreal: ICAO, 2004. https://www.icao.int/Meetings/ AMC/MA/Assembly\%2035th\%20Session/wp085_en.pdf

International Civil Aviation Organization - ICAO. Towards a carbon neutral and eventually carbon free industry. Assembly Working Paper n. A36-WP/85. Montreal: ICAO, 2007. https://bit.ly/2XloplZ

International Civil Aviation Organization - ICAO. Environmental Report. Montreal: ICAO, 2016a. https://bit.ly/2rlkbhz

International Civil Aviation Organization - ICAO. Resolution A39-03. Montreal: ICAO, 2016b. https://www.icao.int/Meetings/a39/Documents/WP/wp_530_en.pdf International Civil Aviation Organization - ICAO. 2016c. "Joint Statement of Argentina, Brazil, China, India, Panama, Russian Federation and Saudi Arabia on International Aviation and Climate Change." Paper present at the ICAO High-Level Conference on Global Market-Based Measures, Montreal, 2016b. https://bit.ly/2MxQ42u

International Civil Aviation Organization - ICAO. "Comments on the cost impact of the proposed global market-based measure (GMBM).” Working Paper n. HLMGMBM-WP/12, presented at the ICAO High-Level Conference on Global Market-Based Measures, Montreal, 2016d. Accessed https://bit.ly/2Xfa8aB

International Civil Aviation Organization - ICAO. The distribution of offsetting obligations under the GMBM. Assembly Working Paper n. A39-WP/234, presented by Brazil. Montreal: ICAO, 2016e. https://www.icao.int/Meetings/a39/Documents/WP/wp_234_ en.pdf

International Civil Aviation Organization - ICAO. Key design elements of the global marketbased measures for international civil aviation: Brazil's position. Assembly Working Paper n. A39-WP/233, presented by Brazil. Montreal: ICAO, 2016f. https://www.icao.int/ Meetings/a39/Documents/WP/wp_233_en.pdf

International Civil Aviation Organization - ICAO. "Alternative proposal to draft assembly resolution text on a global MBM scheme for international aviation: a Brazilian contribution.” Working Paper n. HLM-GMBM-WP/13, presented by Brazil at the ICAO High-Level Conference on Global Market-Based Measures, Montreal, 2016g. https://bit.ly/2EMUgoH 
International Civil Aviation Organization - ICAO. Rankings of State based on International Scheduled and Total Revenue Tonne Kilometres (RTK). Montreal: ICAO, 2016h. https://www.icao.int/sustainability/Pages/RTK_ranking.aspx

International Civil Aviation Organization - "ICAO. Declaration of the Second Conference on Aviation and Alternative Fuels (CAAF/2)." Summary of conclusions and recommendations from the third meeting presented at the ICAO Conference on Aviation and Alternative Fuels, Montreal, 2017. https://bit.ly/2JSQFJC

"Global Aviation CO2 Deal Adopted With Mixed Results, Just As Paris Agreement Takes Off." Flyghtpaht 1.5º, October 6, 2016. https://bit.ly/2I6ddDm

Murphy, A. "If we're going to offset airplanes' carbon emissions, we should at least do it right”. Transport \& Environment, February 16, 2018. https://bit.ly/2C7H5Pu

Schwartzman, S. "Amazon Hydroelectrics, the UN Climate Treaty and the International Civil Aviation Organization (ICAO) - Will Greed and Corruption Derail the International Climate Negotiations?” EDF Talks Global Climate blog, November 8, 2017. http://tiny.cc/3rd15y

Viola, E., and M. Franchini. Brazil and Climate Change: Beyond the Amazon. New York, NY: Routledge, 2017.

Viola, E., M. Franchini, and T. Ribeiro. Sistema internacional de hegemonia conservadora: governança global e democracia na era da crise climática. São Paulo, SP: Annablume, 2013.

World Wildlife Fundation UK - WWF-UK. Greener skies? Supply and sustainability of carbon credits and alternative fuels for international aviation. London: WWF-UK, 2016. https://bit.ly/2drntpP

"Xapuri Declaration: 'We Reject Any Form of Climate Colonialism'." World Rainforest Movement, May 28, 2017. https://bit.ly/2W9M47y 